\section{Re: Sykdomskremmeri eller sykdomssalg?}

Jeg leste Berit Bringedals artikkel om begrepet «diasese mongering» og dets norske oversettelse med stor interesse (1). Steinar Westin har tidligere oversatt begrepet til sykdomskremmeri.

Dersom man ønsker å gi fenomenet et navn med negative konnotasjoner, så vil muligens «sykdomsfabrikkering» være et like godt alternativ som sykdomskremmeri og sykdomssalg. Dette er en direkte oversettelse av det franske «fabrique de malades», som er en foreslått oversettelse til det engelske «disease mongering» (2). I Stortingsmelding nr. 20 «Vilje til forskning» er uredelighet i forskning eksemplifisert blant annet som fabrikkering (3). «Disease mongering» er jo nettopp en uredelighet både i forskning og i markedsføring.

«Disease mongering» er ment å være et begrep med negative konnotasjoner, jmfr. begrepet «fear mongering». Er det nødvendig? For at vi skal ta noe på alvor hjelper det ikke alltid å spøke med det. Et raskt søk i Google Scholar og PubMed gir flere eksempler på bruk av ordet «patologisering», både på engelsk, norsk, svensk og dansk, i samme betydning som «disease mongering» - altså en medikalisering av normaltilstander i mennesket. Kanskje er det tilstrekkelig å bruke et begrep som ikke er ladet, når man beskriver et fenomen som i seg selv er kritikkverdig?

\section{Ane Christine Skurdal \\ anechris@stud.ntnu.no}

Ane Christine Skurdal (f. 1987) er medisinstudent

Ingen oppgitte interessekonflikter.

\section{Litteratur}

1. Bringedal B. Sykdomskremmeri eller sykdomssalg? Tidsskr Nor Legeforen 2014; 134: 1679

2. Wikiédia (fransk versjon). Disease mongering. http://fr.wikipedia.org/wiki/ Disease mongering. (27.9.2014).

3. St meld. nr. 20 (2004-2005) Vilje til forskning. www.regjeringen no/nb/dep/kd/ dok/regpubl/stmeld/20042005/stmeld-nr-20-2004-2005- html?id=406791 (20.10.2014).

\section{Re: Brysomme studenter}

I denne lederen fremhever Erlend Hem hvordan studentenes engasjement er helt avgjørende for å skape god utdanning (1). Samtidig påpeker han at fakultetsledelse og undervisere ofte oppfatter slikt engasjement som brysomt. Dette paradokset tyder på at vi har et fundamentalt problem i hvordan vi organiserer og tenker om utdanning.

Hems artikkel er i seg selv et illustrerende eksempel på hvordan studentengasjementet oftest fremstår som aktivisme. Engasjerte studenter beskrives som opprørere som kjemper mot en innesluttet og avvisende fakultetsorganisasjon, og studentenes egne organisasjoner er plassert på sidelinjen av fakultets ordinære virksomhet. De er riktig nok representert i råd og utvalg, og har stemmerett ved dekanvalgene, men man skal ikke ha sittet i mange komiteer for å se at studentenes stemme er svak og i hovedsak kommer til uttrykk nettopp som aktivisme, f.eks. i forbindelse med innføring av nytt karaktersystem.

Ikke desto mindre er det i de mange studentorganisasjonene at studentene i stor grad former sin identitet som medisiner. Det er her de făr utløp for sin faglige, humanistiske og kunstneriske kreativitet; det er her de får testet og utviklet sine lederegenskaper, og det er i stor grad her de bygger nettverk og møter sine rollemodeller. Det som skjer på sidelinjen av studiet kan derfor være like viktig for dannelsen av samfunnets fremtidige leger som definisjonen av pensum og den formelle undervisningen. I et moderne utdanningsperspektiv, som flytter fokus fra undervisning til læring, er det derfor interessant å se på alternative måter å tilnærme seg studentene og deres organisasjoner.

Hvis målet er å utdanne selvstendige, reflekterende og empatiske leger, må man gi rom for utvikling av disse egenskapene også innenfor studiets rammer. Istedenfor at studentorganisasjonene holdes på sidelinjen, kan man derfor tenke seg et fakultet som i større grad tilrettelegger for det store engasjementet som i dag har trange kår utenfor den offisielle utdanningsarenaen. En slik modell vil innebære at ledelsen og underviserne, innen for definerte rammer, tar et skitt tilbake og lar studentene ta ansvar for egen læring.

Med referanse til studentorganisasjoner som bl.a. Medisinernes seksualopplysning, Medisinstudentenes Humanitæraksjon og medisinstudentenes eget fagutvalg (MFU), er det ingen tvil om at vi har studenter som både kan og vil ta ansvar for faglig og organisatorisk utvikling. Denne ressursen kan med fordel stimuleres, utvikles og i større grad kanaliseres inn i den formelle utdanningsorganisasjonen. Studentengasjementet kan slik dreies fra aktivisme til samarbeid, og de brysomme studentene vil i stedet fremstå som fakultetets stolthet.

\section{Jarle Breivik}

jbreivik@medisin.uio.no

Jarle Breivik (f. 1968) er professor og utdanningsleder ved Institutt for medisinske basalfag, Det medisinske fakultet, Universitetet i Oslo. Ingen oppgitte interessekonflikter.

Litteratur

1. Hem E. Brysomme studenter. Tidsskr Nor Legeforen 2014; 134: 1725. 